\title{
Sraffa and Manara: the mystery of the last article of Piero Sraffa
}

\author{
Yoann Verger
}

February 14, 2018

\begin{abstract}
Piero Sraffa is a most famous economist, as well as a very parsimonious writer. So the discovery of an unpublished draft article in his unpublished papers is surely a big news for the history of economic thought, even more considering its subject: to provide an answer for the devastating article of C. F. Manara [1968]. Here I provide a first conjecture on why this draft has never been published - Sraffa was not able to overcome Manara's argument - and I show how Dupertuis and Sinha [2009] provide a solution that would have allowed Sraffa to publish what would have been his last article.
\end{abstract}

\section{Introduction}

Piero Sraffa is a very peculiar kind of scholar. On the one hand, he is one of the few modern economist where we can say his most important publications are almost all of his publications. As an example, one can read Sraffa's entry in Beaud and Dostaler, 1997, where they list for him 15 "mains publications", whereas I can only count in total for him only 18 "scientific" publications (and, within it, the authorship of only one book - see the appendix for the list of his publications). On the other hand, his influence on history of economic thought is immense, as it is acknowledge by one of his most famous opponents, Paul A. Samuelson:

"Did any scholar have so great an impact on economic science as Piero Sraffa did in so few writings? One doubts it. And there cannot be many scholars in any field whose greatest works were published exclusively in their second half century of life. Piero Sraffa was much respected and much loved. With each passing year, economists perceive new grounds for admiring his genius" Samuelson [2008].

Although his publications were not numerous, Sraffa was writing a lot: his unpublished papers gathers thousands of notes, drafts, comments and citations 
that are currently made available online (the online effort began in 2016). ${ }^{1}$ In this collection of documents, two files are headed as unpublished draft articles: a draft from 1923, on the economics of fascism (D3/3), and a draft written around 1969, titled : "Produzione congiunta di merci a mezzo di merci. Riposta a C F Manara" (D3/14). The latter is the one that I want to focus on here.

I will first discuss Manara's article, explaining why an answer by Sraffa seems important, as this article shakens the most interesting part of Sraffa's analysis (section 2). Then I will present Sraffa's draft (section 3), and explain why, in my opinion, he finally decided not to publish it (section 4). Finally I will present Dupertuis and Sinha's [2009] solution to Manara's problem, and I will show how it would have helped Sraffa to answer his problematic.

\section{Manara's article}

Manara's article was first published in Italian in 1968, and then published in English in 1980 (in Pasinetti, 1980). This article was widely read and cited (we can find in Google Scholar 29 citations for the 1980 article and 45 citations for the initial one), and he is cited in two influential reviews of the Sraffian literature, in Pasinetti's [2012] article headed "Piero Sraffa and the future of economics" and in Samuelson's [2008] article on "Sraffian economics" published in The New Palgrave Dictionary of Economics. So what is its content, and what is at stake concerning its results?

\subsection{Content of Manara's article}

Let us introduced Manara's article by one of the most competent scholar in the field of Sraffian economics, and especially concerning the questions raised by Manara [1968], Bertram Schefold:

"While the first part of Sraffa's 'Production of Commodities by Means of Commodities' received quite considerable attention when the book was first published, the second passed almost unnoticed for some time. The third part on 'Switching of Techniques' stood at the centre of the most interesting controversy on economic theory of the 1960s, but the discussion was again focused on single-product industries. The first exception to this pattern was Manara's article on 'Il modello di Piero Sraffa per la produzione congiunta di merci a mezzo di merci' in the Italian journal L'industria, which appeared in 1968. The author, apart from giving an elegant mathematical formulation for the distinction between basics and non-basics in the

\footnotetext{
${ }^{1}$ The online effort is directed by Giancarlo de Vivo and Murray Milgate with the collaboration of the Wren archivist Jonathan Smith. It is expected to be completed in 2017 and can be found at the following url: https://janus.lib.cam.ac.uk/db/node.xsp?id=EAD\%2FGBR\%2F0016\%2FSRAFFA
} 
case of joint production, ${ }^{2}$ pointed to two of the difficulties of jointproduction systems: namely the likelihood of negative prices being associated with some labour vectors at some rates of profit in almost any joint-production system and the nonexistence of the maximum rate of profit and the standard commodity in certain cases. It was not said whether these were to be considered normal or exceptional. Manara, a mathematician, left the tasks of analysis and interpretation of the 'anomalies' to the economists. Manara failed to note that Sraffa had simply and explicitly assumed that positive prices and a real standard commodity exist (PCMC, sec. 50)-but then Sraffa had failed to indicate under what conditions these assumptions would be fulfilled" (Schefold, 1989, p. 44).

Manara [1968] says that these assumptions would be fulfilled under the condition that, for any system of joint production of commodities by interdependent industries (i.e. with only basic commodities) where $\mathbf{A}$ is the matrix of inputs per industry and $\mathbf{B}$ the matrix of outputs per industry (with commodities in columns and industries in rows), a real solution to the following equation can be found for the scalar $R$ :

$$
\operatorname{det}[\mathbf{B}-(1+R) \mathbf{A}]=0
$$

If a real solution for $R$ cannot be found, then it means that, from this system of joint production, no Standard system can be constructed. In his article, Manara provides two numerical examples, and he shows that, for the second example, a real solution can not be found for $R$; but, and this is important for the following, for his first example also, a real solution cannot be found for $R$. Hence, for both examples, a Standard system cannot be constructed.

\subsection{Consequences of Manara's findings}

Sraffa (1960, Chapter IV) constructs his imaginary Standard system by applying to the initial system of interdependent industries a set of multipliers $\mathbf{x}$, so that the commodities used as inputs are in the same proportions as the commodities used as outputs, bringing out a rate of physical residue $R$. In the Standard system, the following equations hold:

\footnotetext{
${ }^{2}$ In single production (i.e. each industry only produces one commodity, and each commodity is only produced by one industry), basic commodities are the commodities that are directly or indirectly needed for the production of all commodities of the system. In joint production (one commodity can be produced by different industries, and industries can produce several commodities), basic and non-basic commodities cannot be separated so easily. For instance, a commodity that enters all processes of production can be considered non basic in some cases. Sraffa $(1960, \S 60)$ gives a formal (mathematical) definition of the distinction between basic and non-basic commodities that applies for both single and joint production, but he also indicates that, even in the latter case, an economic sense can be given to the distinction: if a tax is imposed on a commodity, and that all prices are impacted by this change, its means that the commodity is basic (Sraffa, 1960, § 65). Then a system with only basic commodities can be said to be a system of interdependent industries: each industry needs all the other ones to ensure its production.
} 


$$
(1+R) \mathbf{x} \mathbf{A}=\mathbf{x B}
$$

Sraffa shows that the rate of physical residue $R$ is also the maximum uniform rate of profits of the initial system. Hence, the construction of an imaginary Standard system helps Sraffa to show that, in a system of interdependent industries, the maximum rate of profits is independent from the prices (it is a "physical" property of the system).

Furthermore, by defining a Standard commodity as a mixed commodity whose commodities are in the same proportion as the commodities in the surplus of the Standard system, and by using this Standard commodity as the numeraire, Sraffa shows that the distribution also appears to be independent from the prices (i.e. it can be known prior to prices, once, for instance, the rate of profits is given). This means that the neoclassical theory of distribution, which is to calculate distribution as optimal prices determined by productivity of factors and preferences of consumers, is wrong; distribution depends on external factors, such as political struggle, institutional rules, ethical arguments, etc.

What are the consequences of Manara's findings? For some cases of joint production, it is not possible to calculate a physical rate of surplus, hence to disconnect distribution theory from price theory. This allows Samuelson to asserts that, because of Manara's findings:

"Sraffa's models, we have by now seen, tellingly reject the following Ricardian stereotypes: ... \{o o ne can correctly understand the distribution of income among workers, landowners, and capitalists independently of the complications of demand theory (consumers' demand functions, marginal utility, revealed preferences, etc.)" [Samuelson, 2008].

But Manara's examples only concern joint production; a physical rate of surplus can always be find if we consider industries that produce only one output. Then the importance of Manara's findings depends on the empirical relevance of joint production. Unfortunately for Sraffa's theory, Pasinetti precisely asserts that joint production is the rule in the real world, and that Sraffa was perfectly aware of this:

"Joint products, i.e. those goods that cannot be produced separately from each other - such as wool and mutton, iron and coke, and so on - were for a long time a subject of only secondary interest in economic theory, although they cropped up regularly, in the economic treatises, in sections devoted to 'complications'. Indeed, if the importance of processes of joint production were limited to such cases, which we may call cases of joint production proper, it would be possible to deal with them as of secondary importance. However, it has recently been realised that the model of joint production is of much more general application than was thought. To be more precise, it has been realised that this model is the one most suitable 
for the analysis of processes of production with fixed capital. This being the case, it would clearly be wrong to carry on talking of it as a secondary subject, since fixed capital production processes, i.e. processes with capital goods that last several years, are the norm in the industrial world.

Sraffa himself uses precisely this argument in justifying the chapters of his book devoted to joint production: 'The interest of Joint Products does not lie so much in the familiar examples of wool and mutton, or wheat and straw, as in its being the genus of which Fixed Capital is the leading species. And it is mainly as an introduction to the subject of fixed capital that the ... chapters devoted to the intricacies of joint products find their place"' (Pasinetti, 1980, p. xii, citation from Sraffa, 1960, $\S 73$ ).

\section{Sraffa's draft}

It is then not surprising that Sraffa attempted to answer Manara, as soon as he heard about his article. I will now present the file containing the drafts of Sraffa's answer, and then describe his content.

\subsection{Content of the file D3/14, transcription of the pre- sumed last version ${ }^{3}$}

The file D3/14 gathers 115 notes (the notes refer sometimes only to one recto page, or to a recto-verso page, or sometimes to a group of pages), which we can order in this way:

- D3/14/2-D3/14/6: first typewritten and annotated draft.

- D3/14/7-D3/14/11: second typewritten and annotated draft (the typewritten draft is identical to the first, but the handwritten additions are slightly different).

- D3/14/13-D3/14/20: handwritten draft.

- D3/14/22-D3/14/23: letter from Pasinetti to Sraffa, dated 4th February 1969, where Pasinetti says that he met Manara in Milan, and presents Manara's problem to Sraffa.

- D3/14/24: letter from Pasinetti to Sraffa, dated 11th December 1969, where Pasinetti says that he quickly read the note made by Sraffa to answer Manara's problem, and makes a comment about it.

- D3/14/25 (pp. 1-18): print of Manara's 1968 article.

${ }^{3}$ The file is available at the following URL: http://trin-sites-
pub.trin.cam.ac.uk/manuscripts/Sraffa_D3_14/manuscript.php?fullpage=1\&startingpage $=1$


- D3/14/26-D3/14/115: handwritten comments and drafts about Manara's problem.

My guess, after reading all the notes, is that the first typewritten drafts (D3/A4/2D3/14/6 and D3/14/7-D3/14/11) are the final version, and that all other handwritten comments and drafts are earlier to it. This last version was probably written after 11 December 1969, i.e. after the second letter from Pasinetti to Sraffa. In this letter Pasinetti tells Sraffa that he shall not use the term "incompatibilità" (which we can find in the handwritten notes, for instance in D3/14/28), but rather the terms "assoluta inferiorità", which convey no mathematical signification while having an economic meaning. In the typewritten draft, we find these terms, and no mention of the term "incompatibilità".

So it seems important to me to present below the integral transcription of this presumed final version. I use [ ] to signal footnotes and handwritten insertions in the margin or above or below the line, and I use \{\} to indicate my additions:

\section{"PRODUZIONE CONG[U]INTA DE MERCI A MEZZO DI MERCI. RIPOSTA A C.F. MANARA}

1 - In un articolo pubblicato su questa rivista (1) Carlo Felice Manara ha presentato un'analisi in termini matematici di un capitolo del mio libro Produzione di merci a mezzo di merci (2) e di questo gli sono grato.

[a capo] \{the next sentences are crossed $\}$ Fin dall'inizio del suo scritto il Manara ha voluto esimersi da ogni responsabilità per il contenuto economico delle ipotesi o esempi che egli propone (3). Questa sarebbe stata una felice ispirazione se forma e contenuto potessero così facilmente essere separati. Ma subito diventa chiaro che la critica che egli fa è appunto basata su di un suo sbaglio di natura economica.

[a capo] Mi era sembrato che la cosa dovesse essere evidente ad ogni economista così da rendere superflua una rettifica. Viceversa, ho constatato recentemente che l'articolo in questione ha messo fuori strada alcuni giovani studiosi; e di qui è sorta la necessità di una riposta. \{end of the crossed section

2 - Prima di venire alla questione essenziale c'è un punto da chiarire. Il capitz[o]le[o] al quale il Manara dedica la sua analisi è intitolato: "Il sistema tipo con prodotti congiunti".(4)

[(1) "Il modello di Piero Sraffa per la produzione congiunta di merci a mezzo di merci', L'industria, 1968, Pag. 3-18.

(2) Edizione Einaudi, 1960; ristampa 1969 con la stessa paginatura.

(3) Manara, pag. 4.

(4) Produzione di merci a mezzo di merc[i], pagg. 59-70. Il "systema tipo è una costruzione che si [o]ttiene applicando alle equazioni che rappresentano le varie industrie (o metodi di produzione) moltiplicatori tali che l'inisieme dei prodotti risulti composto delle stesse 
merci che compongono l'insieme dei mezzi di produzione imiegati; e che le propozioni delle merci fra i prodotti risultino uguali alle loro propozioni fra i mezzi produzione. Il "prodotto tipo" è l'insieme dei prodotti del sistema tipo[, e in quelle proporzioni.]

L'obbiezione principale che egli fa è questa: "non par[/]eche" Sraffa sia stato sfiorato dal minimo dubbio sulla possibilità di immaginare l'esistenza di un prodotto tipo, mentre invece tale possibilità non si verifica in generale ma deve essere postulata mediante una opportuna ipotesi sulla costituzione della matrici" (pag. 12).

[di seguito] La necessaria ipotesi che il Manara arriva ad enunciare dopo due altre pagine di elaborazione è la seguente: "la equazione algebrica nella incognita $r$ [ $r$ é il saggio massimo del profitto] ammette almeno una radice reale e positiva (5)" (pag. 14).

[a capo] A questo punto il Manara deve essersi accorto che tale condizione era già stata posta nel mio libro e cerca di cavarsi di [d']imp[a]ccio con una nota che val la pena di riprodurre integralmente:

[a capo] 'Il termine 'numero reale' e 'soluzione reale' è usato qui [cioè dal Manara] nel senso tecnico preciso della matematica e non nel senso un po' vago in cui è usato in Sraffa pag. 56; in questa ultima paginal, invero, per quanto è dato di poter capire, l'Autore usa l'espressione 'soluzion[i] reali' per dire, forse, 'soluzioni che abbiano significato economico' ovvero ' che abbiano una rispondenza nella realà.["'] (Manara pag. 13 nota).

[(5) \{the next sentence is crossed $\}$ Mentre l'esigenza di una radice reale occuperà il resto di questa riposta, la questione della negatività o no richiede solo poche parole. Ifatti \{end of the crossed section\} [L]a condizione della non-negatività di $r$ era stata messa per tutta la trattazione sin dal principio del libro (Sraffa, p. 6 nota); la positività non è necessaria poichè può essere $r=0$.]

[a capo] Poichè il Manra non ha rituneto utile di riportare il testo d[el] [quale] egli d[à] questa travagliata interpretazione, lo riporterò io: "salvo solo la condizione generale che le equazioni risultanti siano fra di loro indipendenti e che abbiano almeno un sistem di soluzioni reali". (Sraffa, pag. 56). Non occorre altro commento.

3 - $\{$ the next sentences are crossed $\}$ Fin qui il Manara, nonostante il suo tono polemico, in sostanza non fa altro che confermare quanto era stato detto nell'opera che egli critica; e ci si potrebbe chiedere perchè una volta accortosene non abbia ritirato questa parte, divuneta a dir poco superflua, del sua articolo.

[a capo] Ma evidentemente c'è qualcosa di più. E questo qualcosa à la [convinzione che la] esigenza di una soluzione reale (e qui non importa se forumlata dall'autore prima che dal critico) sia talmente restritiva da rendere la costruzione del prodotto tipo generalmente inapplicabile ad un sistema economic normale. Infatti il[/]Manarar per illustrare la inaplicabilità del prodotto tipo presentta un esempio 
numerico così semplice e calzante che, se valido, sarebbe decisivo per confermare tale convinzione.

[a capo] L'esempio è basato su due industrie (cioè due metodi di produzione) ciascuna delle quali produce congiuntamente[,]ed usa come mezzi di produzione, le stesse due merci [ma] in proporzioni diverse. I dati sono presentati in forma di due matrici, la prima $(A)$ per i mezzi di produzione e la seconda $(B)$ per i prodotti: \{end of the crossed section

[in tutti i casi per I leggi 1]

$$
\begin{gathered}
A=\left[\begin{array}{cc}
I & I . I \\
I . I & I
\end{array}\right] \\
B=\left[\begin{array}{cc}
I .09 & I .144 \\
I .144 & 0.99
\end{array}\right]
\end{gathered}
$$

Il Manara dimostra che le risultanti equazioni non hanno soluzioni reali, e quindi non consentono la costruzione del prodotto tipo (pag. 13).

[a capo] \{the next sentences are crossed\} Ma guardiamo ora e questi stessi dati dal punto di vista economico, confrontando cioè i mezzi di produziono delle due industrie con i rispettivi prodotti. Chiamando le industrie I e II e le merci $\underline{c}$ e $\underline{d}$ abbiamo:

[centrare la tabella] Industria I

[centrare il segno +$]$ impiega $1 \underline{c}+1.1 \underline{d}$ produce $1.09 \underline{c}+1.144 \underline{d}$ [spaziare ingualmente a destra e a sinistra di "produce]

Industria II

[centrare il segno +$]$ impiega $1.1 \underline{c}+1 \underline{d}$ produce $1.144 \underline{c}+0.99 \underline{d}$ [spaziare ingualmente a destra e a sinistra di "produce]

Messa la cosa in questi termini salta subito agli occhi che [l'essempio] del Manara è economicamente impossibilie. Infatti la industria II è assolutamente inferiore all'industria I, poichè sia per la merce $\underline{c}$ che per la merce $\underline{d}$ l'industria II dà un rapporto fra quantità prodotta $\mathrm{e}$ quantità impiegata inferiore a quello dell'industria I. E precisamente:

[centrare la tabella]

$\left[\begin{array}{lllll} & & \text { Industria I } & & \text { Industria II } \\ {[\text { [meno spazio ai due lati di }>\text { per la merce } \underline{c}} & \frac{1.09}{1} & >\text { [meno spazio] } & \frac{1.144}{1.1} \\ \text { [meno spazio ai due lati di }>\text { ] } & \text { per la merce } \underline{d} & \frac{1.144}{1.1} & >\text { [meno spazio] } & \frac{0.99}{1}\end{array}\right.$

\{the table is also crossed

E' questa assoluta inferiorità di un'industria rispetto all['] altra che rende impossibilie in questo caso di costruire il prodotto tipo.

[a capo] Si può aggiungere, per finire, che questa stessa assoluta inferiorità ha ben altre conseguenze. Infatti, cosa che è stata 
ignorato dal Manara, le stesse ragioni che rendono nel suo caso impossibilie la costruzione del prodotto tipo renderebbero impossibile anche l'esistenza di un saggio del profitto uniforme nelle varie industrie e di un prezzo uniforme per tutte le unità di una stessa merce.(6) \{end of the crossed section

[(6) Alla fine del suo articolo (pag. 18), il Manara chiede una spiegazione poichè, egli dice, lo Sraffa "non pare si sia preoccupato di dare una interpretazione a quantità di laoro negative assorbite da industrie". La spegazione si trova in un passo che il Manara, per usare la sua propia frase, "non pare si sia preoccupato" di leggere, e precisamente a pag. 60-61 del libro [in questione] dove si dice: "non potendosi dare un significato quasiasi alle 'industrie negative' che tali moltipicatori negativi porterebbero con se', diventa impossiblie rappresentarsi il sistema tipo come un concepibilie riproporzionamento delle industrie reali. Dobbiamo quindi, nel caso di prodotti conguiunti, accontentarci del sistema di equazioni astratte, trasformato da opportuni moltiplicatori, senza tentare di immaginare che esso abbia une esistenza concreta". Quanto al prodotto tipo (che è la sola ragion d'eessere del sistema tipo), esso è composto esclusivamente di merci e non comprende quantità di lavoro.]" (Sraffa's unpublished papers, D3/14: 2-6).

\subsection{Comments}

Sraffa, then, only considers the second numerical argument of Manara, and dismisses it because it has no economic meaning: in empirical reality, this system could not appear because the second industry is absolutely inferior to the first one, and would be then ruled-out by competition.

Besides Pasinetti, this draft may have been also presented to Schefold, who was in Cambridge at that time. ${ }^{4}$ In his PhD thesis, Schefold uses exactly the same argument to explain that, in a case of "imbalance" of one industry, as in the second numerical example of Manara, no standard system can be constructed:

"Consider (it makes sense for $n=2$ ) systems with $\mathbf{A}>\mathbf{O}$.

$$
g_{i}^{j}=\frac{b_{i}^{j}}{a_{i}^{j}}(i, j=1,2)
$$

is the rate of reproduction of good $j$ in process $i$.

We define: a system involving two goods and two processes is imbalanced if one process is better than the other for both goods in that

$$
\left(g_{i}^{1}, g_{i}^{2}\right)>\left(g_{j}^{1}, g_{j}^{2}\right) \text { for }(i, j)=(1,2) \text { or }(2,1)
$$

\footnotetext{
4"My PhD thesis 'Mr Sraffa On Joint Production' ... was written in 1969/70 when I was first a Visitor to the Faculty of Economics, then an Advanced Student at King's College, Cambridge" (Schefold, 1989p. vii).
} 
The example proposed by Professor Manara is inefficient in this sense

\section{Theorem}

If the inefficiency above (imbalance) is ruled out, a positive standard ratio $R$ and a positive $\mathbf{q}$ and $\mathbf{p}(R)$ exist" (Schefold, 1989, p. 146).

But Schefold also goes a bit further, by defining the condition where, in joint production systems with more than two interdependent industries, a standard system can be constructed (Schefold, 1989, p. 96-99). This condition is that, for all $a_{i}^{j}$ and $b_{i}^{j}$, we should observe (possibly after having made the right substitutions of rows and columns in matrices $\mathbf{A}$ and $\mathbf{B}$ ):

$$
0 \leq \frac{b_{i}^{j}}{a_{i}^{j}}<1+R<\frac{b_{j}^{j}}{a_{j}^{j}} \leq \infty
$$

Schefold, by assuming the above condition, can then also avoid cases such as the one presented in the first numerical example of Manara. Unfortunately for Sraffa's theory, this above condition is rather strong ("slightly more stringent", as it is acknowledge by Schefold 1989, p. 97): for instance an industry where two (or more) of the joint outputs are not also used as inputs by the same industry should be ruled-out, and so independently of the input-output coefficients of the other industries. Hence, this condition seems to convey no real economic significance.

He concludes his development on this above condition by saying:

"The main insight obtained in this section is the one derived from the von Neumann model: systems without a semi-positive standard commodity and semi-positive $\mathbf{p}_{t}(R)$ suffer from specific inefficiencies revealed at $r=R$, much in the same way as systems that are almost all-productive are susceptible to suffer from inefficiencies revealed at $r=0$, but covered at $r=\bar{r}>0$. Both these inefficiencies occur in systems where the possibility of substitution is inherent: they are not all-engaging and yet basic" (Schefold, 1989, p. 98).

Hence, as Sraffa, he explains the fact that in some cases of joint-production, a standard system can not be constructed, by the fact that some industries are less efficient than others. But the condition for the existence of a standard system when the number of industries are more than two is more a mathematical one than an economic requirement.

\section{Why Sraffa did not publish it?}

In this section I try to formulate a plausible conjecture explaining why Sraffa decided not to publish the above draft. But first, several guesses can be attempted to explain the non-publication. 


\subsection{Guesses}

A first guess is that he did not find the subject important enough to respond in a public way (but he may have had a private explanation with Manara).

Three supports can be advanced for this guess. A first support is the fact that in opening sentences of the above draft, he says that he was not sure that an answer was necessary ("Mi era sembrato che la cosa dovesse essere evidente ad ogni economista così da rendere superflua una rettifica"). But I understand this more as a sarcastic way to introduce the subject.

A second support is a remark of Schefold, that, once, Sraffa told him that there have been too much discussion on joint production:

"When he $\{$ Sraffa $\}$ was confronted with the difficulties of joint production systems, which had surfaced in the 1960s and early 1970s, he told me that, if he had known, he should have written much less about general joint production systems and more about fixed capital and land, and that he would have liked to treat only part of the problematic of joint production and, finally, that it might have been better to begin the exposition with the analysis of fixed capital, followed only by some thoughts on joint production in general" (Schefold, 2005).

The last support for this guest comes from Pasinetti himself, responding to an email where I asked him why Sraffa did not published the above draft:

"Dear Mr. Verger,

Thank you for contacting me.

After almost 60 years, I do not recall why Piero Sraffa decided not to publish a reply to Manara's 1968 article.

My presumption is that in the end he became convinced that it was not necessary.

My best wishes for your research work.

Sincerely yours,

Luigi Pasinetti" (personal communication, October 5th, 2017).

From these two points of view, the guess that Sraffa thought this discussion on joint production not important is indeed convincing. ${ }^{5}$

But, besides my argument in subsection 2.2, we can also find in the drafts some arguments that do not support this guess. First more than hundred pages of notes in the D3/14 file show that Sraffa spend lot of time on the subject,

\footnotetext{
${ }^{5}$ And this is also the point of view of Samuelson:

"As Carlo Manara (1980, pp. 9-11) has shown, there may exist no real characteristic vectors to serve as a standard commodity for admissible singletechnique joint product systems.

A catastrophe? No, no catastrophe. There was little of value (to me, to Ricardo, to Sraffa) to be lost and no tragedy in the Manara finding that some $b-a$ matrixes lack real-number characteristic Sraffian vectors." (Samuelson, 2000).
} 
trying to express his answer in the best possible way. Second, we find in the file some notes saying that if the article were right, it would shaken the whole classical tradition starting with Adam Smith, for example in the following note:

"Si può concludere che la generalità della costruzione di un prodotto tipo, e con non e diversa da quella che [non è soggesta a condizioni più restrittive di quella] di qualunque[siasi] altra teoria generale di un sistema di industrie interdipendenti[.] la capace di mantenersi

Se questo fosse vero il M. non solo avrebbe demolito [schiacciato] la mia povera [mosta] capanne ma, nuovo Sansone, avrebbe fatto crollare tutto i édificio colonnate dell' economia moderna. che Adam Smithin

Se nell'esempio del Manara cambiano l'ultimo membro da $0.99 d$ a $1.09 d$ il caso diventa possibile: e il sistema si trove già formato in sistema tipo, con il saggio massimo del profitto che può essere calcolato in termin della une o dell'altro merce, $=\frac{2.234-2.1}{2.1}=\frac{0.133}{2.1}$ o $6,6 \ldots \%$." (Sraffa's unpublished papers, D3/14: 61).

Or again in this note:

"Se l'esempio fosse valido con la mia poverite costruzione crollenbbero anche i pilaobri della economia tradizionali" (Sraffa's unpublished papers, D3/14: 63).

A second guess for the non-publication is that Sraffa did not find it important to answer himself, as Bertram Schefold was going to publish his thesis on this subject. We can advance two support for this guess: first we know that Sraffa and Schefold were close, as we can see it in a draft of a letter from Sraffa to Schefold, dated 10 October 1974, which is also in the unpublished papers of Sraffa:

"[10 Oct 74 not sent found his of 10 Sept $74 !]$

Dear Schefold,

Why on earth did you hesitate? I am delighted to hear from you, hope to hear more, + above all hope to see you! As a first instalment I shall be glad to see Dr Pennavja.

10 Oct. 74

The above was written when I received your letter of 24.6.74. Then both got buried in the chaos of my papers and came to the surface only this day. Cristina Pennavaria came on July 5 and I was delighted to meet her." (Sraffa's unpublished papers, C279_5).

A second support can be find in the fact that Sraffa was used to send young colleagues in theoretical controversies (as Keynes did with him when he needed some help against Hayek), especially when the controversy went on mathematical grounds. For instance see this report from Sinha on the beginning of the Cambridge controversy: 
"Apparently, Paul Samuelson at the MIT, Cambridge, Massachusetts, had set his doctoral student David Levhari the task of disproving a proposition of Sraffa regarding "re-switching of techniques." Levhari published his refutation of Sraffa's proposition in the Quarterly Journal of Economics in 1965.

Geoffrey Harcourt once recounted to me that he was perhaps the first person in Cambridge, UK, to have come across this paper by Levhari at the Applied Economics Library. He went straight to Sraffa and told him that "there is a chap at MIT Cambridge who claims that your re-switching proposition is false."

Sraffa responded: "No, he is wrong, and you show it to him!"

Harcourt responded: "Me? I can't do matrix algebra."

To which Sraffa responded: "Neither can I."

So Luigi Pasinetti was asked to do the job, and the rest is history."

(Ajit Sinha, Inet Blog, consulted the 04/01/2017, https://www.ineteconomics.org/perspectives/blog/ revolution-in-economic-theory)

I can not really provide any fact against this guess; the better way to prove or dismiss it would be to ask Bertram Schefold about it. The only thing that makes me think that it is not the right option is that the third guess is plausible.

Here is the third guess: it does not find his response convincing enough. This is an obvious guess considering that large parts of the final version which are crossed. And this would not be actually surprising knowing that Sraffa is a meticulous writer, only giving talks or publishing writings when he is absolutely sure of the quality of their content. So one would be not surprised if, in the drafts, we found a logical mistake that would have, ultimately, prevented Sraffa to publish the article.

\subsection{Conjecture: a logical mistake?}

We have a first hint that he was not satisfied by his answer in some notes in the file D3/14, for instance here:

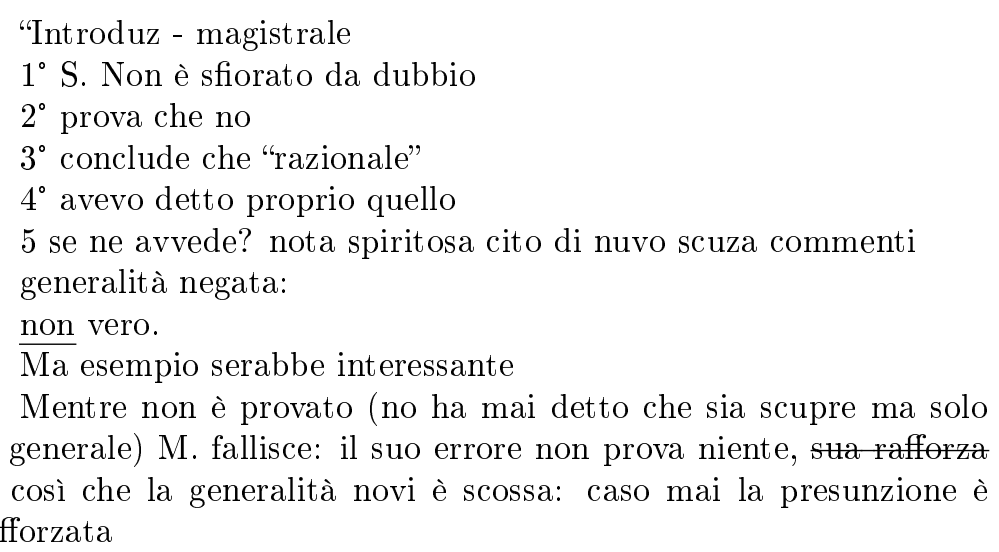


Il fallimento di M. rinforze la presuzione che nei casi economicamente possiblii non c'è è generale Ma sarebbe interessanta se qualcuno che maggio pazienza e fortuna del M. lo trovarse

Si noti che

L'esempio del M., non solo era stato esclusivo dall condiz. di soluzioni reali che avevo fatti explicitamente ; ma sarebbe stato esclusi dalla condizione prelim [economica] elementare the il sistema [della convenienza]. che si tratti di un sistema capace vitale capace

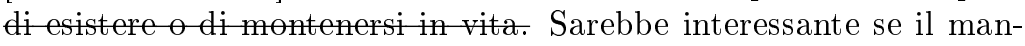
ara o qualcuno [più paziente] mene meno sfortunato di lui trovarse un esempio di un sistema di prodotti base [in sè] economicamente accettabile [possibile], che non avesse soluzione raz. per il sistema la merce tipo." (Sraffa's unpublished papers, D3/14: 72-74).

Sraffa thinks that his explanation does not prove in a general way that Manara is wrong, and that if an example were to be found where no industry shows "assoluta inferiorità" and no standard system can be constructed, then it would be a bad hit for his theory.

But this is actually precisely the case of the first numerical example of $M a-$ nara. It is then possible that Sraffa, discovering this fact, finally decided not to publish his draft; the part where he exposes that it is because of the "assoluta inferiorità" that Manara's example does not work is totally crossed in the draft above, which can be explained if he found that the first numerical example of Manara shows no "assoluta inferiorità" while also being a case where no standard system can be constructed.

We saw in subsection 3.2 that Schefold has also seen that, if there is more than two interdependent industries, the argument of "imbalance" does not work anymore. But he did not find a real economic reason to dismiss cases such as the first numerical example of Sraffa, and he only found a mathematical condition to avoid such cases. I believe that Sraffa could have been happy with such case, as he always wanted to link theory with empirical facts that one could observe (on the objective approach of Sraffa, see Sinha, 2012).

\section{Dupertuis and Sinha's solution to Manara's prob- lem: interdependent industries and self-reproducing system}

Dupertuis and Sinha [2009] show that is possible to dismiss both numerical examples of Manara while giving an economic meaning to this dismissal. The key notion is interdependence, or rather "mutual dependence":

"It is desirable at this stage to explain why the ratios which satisfy the conditions of production have been called 'values' or 'prices' rather than, as might be thought more appropriate, 'costs of production'. 
The latter description would be adequate so far as non-basic products were concerned, since, as it follows from what we have seen in the preceding section, their exchange ratio is merely a reflection of what must be paid for means of production, labour and profits in order to produce them - there is no mutual dependence.

But for a basic product there is another aspect to be considered. Its exchange-ratio depends as much on the use that is made of it in the production of other basic commodities as on the extent to which those commodities enter its own production" (Sraffa, 1960, §7).

We have to remember that Sraffa considers only systems of productions where at least one basic commodity is existing, i.e. where at least a minimum level of interdependence between industries exists. This is why the title of his book is "Production of commodities by means of commodities": he explicitly rejects systems with no interdependence. This is why also the possibility that an "ultimate" commodity is produced only by labour is explicitly rejected by Sraffa:

"The notion of a Maximum rate of profits corresponding to a zero wage has been suggested by Marx, directly through an incidental allusion to the possibility of a fall in the rate of profits 'even if the workers could live on air'; but more generally owing to his emphatic rejection of the claim of Adam Smith and of others that the price of every commodity 'either immediately or ultimately' resolves itself entirely (that is to say, without leaving any commodity residue) into wage, profit and rent - a claim which necessarily presupposed the existence of 'ultimate' commodities produced by pure labour without means of production except land, and which therefore was incompatible with a fixed limit to the rise in the rate of profits." (Sraffa, 1960, Appendix D, § 3)

The smaller possible system that Sraffa could investigate is thus a self-reproducing process (see his introduction of The Works and Correspondence of David Ricardo, 1951-1973; where he introduces an example with only one self-reproducing corn industry). A process may be said self-reproducing if it produces enough commodities to reproduce itself without the need to exchange some commodities with other processes [Dupertuis and Sinha, 2009]. Sraffa only deals with systems that can possibly be transformed, through appropriate multiplications, into self-reproducing systems:

"This formulation presupposes the system to be in a self-replacing state; but every system of the type under consideration is capable of being brought to such a state merely by changing the proportion in which the individual equations enter it", (Sraffa, 1960, § 3, footnote).

However, inside a self-reproducing system, all processes must be non-self-reproducing. This is because prices are defined in the theory of Sraffa as the exchange ratios that will allow the system to reproduce itself (and to distribute the surplus according to a given social rule): 
"There is a unique set of exchange-values which if adopted by the market restores the original distribution of the products and makes it possible for the process to be repeated" (Sraffa, 1960, § 1).

If a process is self-reproducing, there is no need for this process to make exchanges with other processes in order to reproduce itself. The price of the commodity produced by this process and its rate of profits are then determined by the conditions of production of this process only: the interdependence is broken.

Now comes the subject of joint production. If a non-self-reproducing process produces two outputs, the right method to find the Sraffian prices of each single output is to add an other non-self-reproducing process producing the same two outputs, as Sraffa itself explains it (Sraffa, 1960, $\S 50$, footnote 2 ). But, if a selfreproducing process jointly produces two outputs, it is not possible to define the Sraffian price of each single output. It is of course possible to calculate prices, if we add to this self-reproducing process an other process of production (either self-reproducing or not). But these prices cannot be the Sraffian prices of the two joint products, as no exchanges are needed between both processes. These prices are not the "exchange-values which if adopted by the market restores the original distribution of the products and makes it possible for the process to be repeated".

Hence, to the previous restriction that "we shall assume throughout that any system contains at least one basic product" (Sraffa, 1960, §6), we must add that, in case of joint production, the system of production must only contain one self-replacing subsystem, as the notion of "mutual dependence" associated with basic commodity in single production is lost if there is more than one self-replacing subsystem in joint production (see Dupertuis and Sinha, 2009).

The implication of the lack of such conditions is the apparent impossibility to build a standard system. However this difficulty is only apparent: following the method displayed in Dupertuis and Sinha [2009], in order to construct the standard system, we will have to limit the system to the self-reproducing sub-system. If there is several self-reproducing sub-systems, several standard systems can be constructed. But, as we already said, it is true that, if in the self-reproducing sub-system the number of commodities produced is higher that the number of processes, some prices will stay indeterminate.

\section{Conclusion}

Focusing on self-reproducing systems with interdependent industries, we can always construct the standard system, and thus we can always express the rate of physical residue of such systems. Thus an economic reason to dismiss Manara's numerical argument is found.

Remember the second numerical example (the processes are in column) :

$$
A=\left[\begin{array}{cc}
I & I . I \\
I . I & I
\end{array}\right]
$$




$$
B=\left[\begin{array}{cc}
I .09 & I .144 \\
I .144 & 0.99
\end{array}\right]
$$

We can see clearly that the first process does not need the second to reproduce itself: it is self-reproducing (while the second process is not, as only 0.99 of the second commodity is produced whereas one unit is required as input). We can then limit the analysis at the first process, the second being a "non-basic" process.

And here is the second numerical example of Manara (processes are again in column):

$$
\begin{gathered}
A=\left[\begin{array}{lll}
1 & 2 & 1 \\
2 & 1 & 3 \\
1 & 2 & 2
\end{array}\right] \\
B=\left[\begin{array}{lll}
2.9 & 1.2 & 1.9 \\
1.2 & 2.9 & 3.9 \\
0.1 & 1.2 & 3.9
\end{array}\right]
\end{gathered}
$$

Here, it is the third process which is self-reproducing. Thus there is no need to take into account the two others to search for rate of physical residue of this system.

What would have been history if Sraffa had find this way to dismiss Manara's argument? Surely it would have been much harder for neoclassical theorists such as Samuelson to argue that Sraffa's theory is just a special case of the neoclassical theory.

Of course, it may be that my conjecture is wrong, and that Sraffa, after some attempts to respond, "became convinced that it was not necessary." But I do not think so. Looking at the notes in the D3/14 file, one can see the urgent need of Sraffa to try to save his life work. And one can only wonder how broken was his heart when he finally crossed out the last version of what would have been his last article.

\section{$7 \quad$ Appendix}

Here is the list of all Sraffa's scientific publications, defined as publications in scientific journals, academic publications and book publication and edition:

1. Monetary inflation in Italy during and after the war. 1920, doctorate thesis.

2. The bank crisis in Italy. 1922, Economic Journal 32, June, pp. 178-97.

3. Obituary of Mafeo Pantaloni. 1924, Economic Journal 34, December, pp. 648-653. 
4. On the relations between cost and quantity produced. 1925, Annali di economia, 2 , pp. 277-328

5. A short review of Hastings, H.B., Cost and Profit: their relation to business cycles, Boston: Houghton Mifflin, 1923. 1925, Giornale degli Economisti, 66, July, pp. 389-390.

6. Two short reviews of Lehfeldt, R.A., Money, London, Oxford University Press, and of Segre, M., Le banche nell'ultimo decennio, con particolare riguardo al loro sviluppo patologico nel dopoguerra, Milano, La Stampa Commerciale. 1926, Giornale degli Economisti, 67, April, p. 230.

7. The laws of returns under competitive conditions. 1926, Economic Journal, 36, December, pp. 535-550.

8. A short review of Phillips, H.W., Modern foreign exchange and foreign banking, London, Macdonald and Evans. 1927, Giornale degli Economisti, 68, October, p. 610.

9. Symposium on increasing returns and the representative firm: a criticism. 1930 Economic Journal, 40, March pp. 89-92

10. Symposium on increasing returns and the representative firm: a rejoinder. 1930, Economic Journal, 40, March p. 93.

11. An alleged correction of Ricardo. 1930, Quarterly Journal of Economics, 44, May pp. 539-544.

12. Dr. Hayek on money and capital. 1932, Economic Journal, 42, March, pp. $42-53$.

13. [Money and capital]: a rejoinder, 1932, Economic Journal, 42, June, pp. 249-251.

14. David Hume's, An Abstract of a Treatise on Human Nature (1740) (Ed. with Keynes). 1938, Cambridge, Cambridge University Press.

15. The works and correspondence of David Ricardo (Ed.). 1951-1973, Cambridge, Cambridge University Press.

16. Malthus on public works. 1955, The Economic Journal, Vol. 65, No. 259, September, pp. 543-544.

17. Production of commodities by means of commodities: prelude to a critique of economic theory. 1960, Cambridge, England, Cambridge University Press.

18. Production of commodities: a comment. 1962, Economic Journal, vol. $72,477-9$. 
Of course, we could also cite the numerous scientific publications where his letters (for instance Bharadwaj, 1970), unpublished papers (for instance Sinha, 2016) or interventions in conferences (see for instance Hague and Lutz, 1961, pp. 305-306 and 325) have been presented or cited, but they were not intended to be published by Sraffa, even if he sometimes approved the publication.

We can also note his activity as a journalist, by listing his publication in periodics, which are few:

1. Open shop drive, 1921, L'Ordine Nuovo, 5 July, p. 3

2. Industriali e governo inglese contro i lavoratori, 1921, L'Ordine Nuovo, 24 July, p. 3

3. I "Labour Leaders", 1921, L'Ordine Nuovo, 4 August, pp. 1-2.

4. Italian Banking To-Day, 1922, The Manchester Guardian Commercial, Reconstruction in Europe, Supplement no. 11, December 7, 675-6

5. The methods of Fascism. The case of Antonio Gramsci. 24 octobre 1927, The Manchester Guardian

We can finally also cite two exchanges of letters that were published with the consent of Sraffa in periodics:

1. Problemi di oggi e di domani, 1924, letter to A. Gramsci published in L'Ordine Nuovo, 1-15 April, p. 4.

2. Polemica monetaria, 1927, two letters to A. Tasca published, with Tasca's reply, in Lo Stato Operaio, 1, November, pp. 1089-1095.

\section{References}

Michel Beaud and Gilles Dostaler. Economic Thought Since Keynes, A History and Dictionary of Major Economists. Routledge, London, 1997.

Krishna Bharadwaj. On the maximum number of switches between two production systems. Schweizerische Zeitschrift für Volkswirtschaft und Statistik, 106(4):409-429, December 1970.

Michel-Stéphane Dupertuis and Ajit Sinha. Existence of the standard system in the multiple production case: a solution to the manara problem. Metroeconomica, 60(3):432-454, 2009.

D. C. Hague and F. A. Lutz, editors. The theory of capital, New York, 1961. International Economic Association, Stockton Press.

C. F. Manara. Ii modello di sraffa per la produzione congiunta di merci a mezzo di merci. L'industria, 1:3-18, 1968. 
C. F. Manara. Sraffa's Model for the Joint Production of Commodities by Means of Commodities, chapter 1, pages 1-15. Macmillan, London, 1980.

L. L. Pasinetti, editor. Essays on the theory of joint production. The MacMillan Press LTD, 1980. doi: 10.1007/978-1-349-05201-1.

Luigi L. Pasinetti. Piero sraffa and the future of economics. Cambridge Journal of Economics, 36:1303-1314, 2012.

David Ricardo. The Works and Correspondence of David Ricardo. Cambride University Press, Cambridge, 1951-1973.

P. A. Samuelson. Sraffa's hits and misses, chapter 3, pages 111-151. Cambride University Press, 2000.

Paul A. Samuelson. Sraffian economics. In Steven N. Durlauf and Lawrence E. Blume, editors, The New Palgrave Dictionary of Economics. Palgrave Macmillan, Basingstoke, 2008.

B. Schefold. Joint production: triumph of economic over mathematical logic? European Journal of the History of Economic Thought, 12(3):525-52, 2005.

Bertram Schefold. Mr Sraffa on joint production and other essays. Unwin Hyman, London, 1989.

Ajit Sinha. Listen to sraffa's silences: an new interpretation of sraffa's production of commodities. Cambridge Journal of Economics, 36:1323-1339, 2012.

Ajit Sinha. A revolution in economic theory. The economics of Piero Sraffa. Palgrave Macmillan, 2016.

Piero Sraffa. Production of Commodities by Means of Commodities. K. K. Vora, Vora \& Co, Bombay, 1960. 